Original Article

\title{
Cytogenetic abnormalities in patients with hematological malignancies in Lahore city, Pakistan
}

\author{
Anormalidades citogenéticas em pacientes com neoplasias hematológicas na cidade \\ de Lahore, Paquistão
}

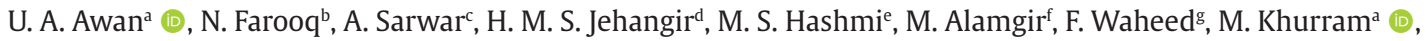 \\ H. Ahmed ${ }^{\text {h }}$ (D) A. A. Khattaki (D) and M. S. Afzala* (D)
}

aDepartment of Life Sciences, School of Science, University of Management and Technology (UMT), Lahore, Pakistan

bLahore Medical and Dental College, Lahore, Pakistan

${ }^{\mathrm{c} G u j r a n w a l a ~ M e d i c a l ~ C o l l e g e, ~ G u j r a n w a l a, ~ P u n j a b, ~ P a k i s t a n ~}$

dMayo Hospital Lahore, Lahore, Pakistan

eBahria International Hospital, Lahore, Pakistan

fPunjab Institute of Cardiology, School of Allied Health Sciences, Lahore, Pakistan

gPunjab University, Department of Microbiology and Molecular Genetics, Lahore, Pakistan

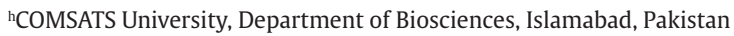

iThe University of Haripur, Department of Medical Laboratory Technology, Haripur, Khyber Pakhtunkhwa, Pakistan

\begin{abstract}
Hematological and hematopoietic cells malignancies of the genes and hematopoietic cells are associated with the genetic mutation, often at the chromosomal level. The standard cytogenetic study is widely accepted as one of the main diagnostics and prognostic determinants in patients. Therefore, the current descriptive and crosssectional study sought to determine the cytogenetic analysis of frequent hematological malignancies in Pakistan. A total of 202 peripheral bone marrow or blood samples from patients with benign and malignant hematological malignancy were taken using a conventional G-banding technique. Among enrolled patients, the mean age was 21.5 years \pm 23.4 , and gender-wise distribution showed a marked predominance of the male 147 (73\%) population compared to the female 55 (27\%). Patients in the age group (2-10 years) had the highest frequency, 48 (24\%), of hematological neoplasms, followed by age (11-20 years) with 40 (20\%). Normal karyotypes (46, XX/46, XY) was found in $51 \%(n=103)$ patients. Furthermore, the frequency of complex karyotype was $30(15 \%)$, while normal was seen in 171 (85\%) patients. Pre-B Acute Lymphoblastic Leukemia (Pre-B ALL) was the most prevalent malignancy of 66 (33\%), followed by Chronic Myelogenous Leukemia (CML) of 41 (20\%) and Acute Lymphocytic Leukemia of 29 (14\%). Translocation was the most prevalent 50 (25\%), followed by hypotriploidy 14 (7\%) and monosomy $8(4 \%)$ on chromosome aberration analysis. In addition, $\mathrm{t}(9: 22)$ translocation was found to be $20(10 \%)$ in CML, with the majority in the age group (31-40 years). This study recommends that karyotyping should be tested frequently in hematological conditions because it may provide insight into the relative chromosomal changes associated with particular malignancies.
\end{abstract}

Keywords: cytogenetic testing, hematological malignancies, chromosomes, leukemia.

\begin{abstract}
Resumo
As neoplasias hematológicas e de células hematopoiéticas dos genes e as células hematopoiéticas estão associadas à mutação genética, geralmente em nível cromossômico. $O$ estudo citogenético padrão é amplamente aceito como um dos principais determinantes diagnósticos e prognósticos em pacientes. Portanto, o presente estudo descritivo e transversal buscou determinar a análise citogenética de neoplasias hematológicas frequentes no Paquistão. Um total de 202 amostras de medula óssea periférica ou sangue de pacientes com malignidade hematológica benigna e maligna foi coletado usando uma técnica convencional de banda G. Entre os pacientes inscritos, a média de idade foi de 21,5 anos $\pm 23,4$, e a distribuição por gênero mostrou uma marcada predominância da população masculina de 147 (73\%) em comparação com a feminina de 55 (27\%). Pacientes na faixa etária (2-10 anos) tiveram a maior frequência, 48 (24\%), de neoplasias hematológicas, seguida da idade (11-20 anos) com 40 (20\%). Cariótipos normais $(46, \mathrm{XX} / 46, \mathrm{XY})$ foram encontrados em $51 \%(\mathrm{n}=103)$ dos pacientes. Além disso, a frequência de cariótipo complexo foi de 30 (15\%), enquanto normal foi observada em 171 (85\%) pacientes. Leucemia linfoblástica aguda pré-B (LLA Pré-B) foi a doença maligna mais prevalente de 66 (33\%), seguida por leucemia mieloide crônica (LMC) de 41 (20\%) e leucemia linfocítica aguda de 29 (14\%). A translocação foi o 50 mais prevalente (25\%), seguido por
\end{abstract}

*e-mail: sohail.ncvi@gmail.com

Received: March 16, 2021 - Accepted: May 3, 2021 
hipotriploidia 14 (7\%) e monossomia 8 (4\%) na análise de aberração cromossômica. Além disso, a translocação t (9:22) encontrada foi de 20 (10\%) na LMC, com a maioria na faixa etária (31-40 anos). Este estudo recomenda que o cariótipo deve ser testado com frequência em condições hematológicas porque pode fornecer informações sobre as alterações cromossômicas relativas associadas a doenças malignas específicas.

Palavras-chave: teste citogenético, malignidades hematológicas, cromossomos, leucemia.

\section{Introduction}

Hematological disorders are typically associated with hematopoietic stem cells mutations and chromosomal aberrations such as aneuploidy or euploidy (Zagozdzon and Golab, 2015), including leukemias (acute/chronic), lymphomas, myelomas, aplastic anemia (AA), chronic myeloproliferative disorders (CMPD), and myelodysplastic syndromes (MDS) (Trejo et al., 2017).

In cancer patients, hematological malignancies ranked among the top 10 leading malignant diseases in incidence and mortality. Collectively, they account for about $9 \%$ of all cancer patients reported annually (Siegel et al., 2011). On their own, leukemias and lymphomas are widespread hematological malignancies, accounting for $2.8 \%$ of all cancer cases worldwide (Richkind, 2012). The annual rates of incidence of several of these cancers are steadily increasing. However, there has been a considerable reduction in mortality owing to such hematological malignancies (Prakash et al., 2016; Siegel et al., 2011). Generally, this positive development is due to robust diagnostic approaches over the last decade or so, primarily due to genetic advancement in the area of hemato-oncology and its application (Prakash et al., 2016; Sánchez et al., 2014). Cytogenetic testing also includes diagnostic tools and vital knowledge of malignancies for hemato-oncologists, helping physicians to determine the patients' prognosis, diagnosis, and effective anti-cancer treatment and monitor their response.

More than $50 \%$ of hematological malignancies have been characterized by clonal chromosomal anomalies dependent on the number of chromosomes (hyperdiploidy, trisomy, or monosomies) or chromosome structure (translocations, inversions, deletions) (Haus et al., 2012; Trejo et al., 2017). Any karyotype can practically be referred to as a "complex karyotype" with at least three aberrations of the chromosome, irrespective of their type and structure (Döhner et al., 2010; Mrózek, 2008). Studies indicated that complex cytogenetics might have adverse effects and a higher risk of relapse with conventional treatment (Röllig et al., 2011; Mrózek et al., 2012; Zappes et al., 2014). In nonmalignant diseases, however, the significance of cytogenetic analysis remains unclear; at a certain point, they either become malignant or remain benign (Waheed et al., 2018).

Since hematological malignancies are prevalent in Pakistan, cytogenetic research of this kind is limited. Therefore, the current study was carried out to calculate the prevalence of different cytogenetic abnormalities in hematological disorders.

\section{Methodology}

This study was performed as a descriptive cross-sectional study in the Department of Cytogenetics, Prime Laboratories Lahore. Patients were referred from different government and private hospitals across the country from adult and pediatric hematology departments, as shown in Figure 1. A total of 202 patients diagnosed with leukemias (acute) chronic), lymphomas, CMPD, and MDS were included. All hematological malignancies are diagnosed in compliance with the World Health Organization (WHO) guidelines.

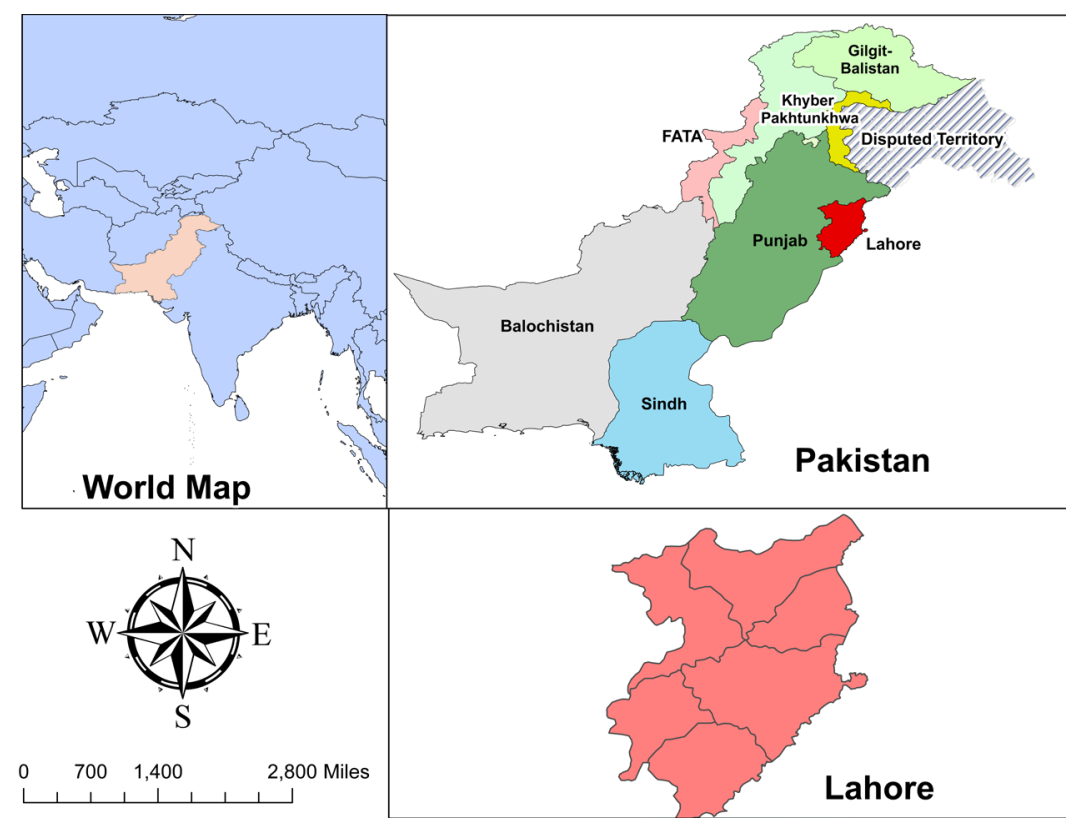

Figure 1. Study area map in Pakistan. 
During a one-year study (Jan-2019 to Dec-2019), all the samples were processed for cytogenetic analysis, and results were reported following the International System for Human Cytogenetic Nomenclature (ISCN) (Shaffer et al., 2013). In addition, the different variables of the study included: age, gender, type of sample (bone marrow aspiration or peripheral blood), karyotyping analysis.

During the karyotyping analysis, five steps were followed: (1) Cell culture; (2) Cell harvesting; (3) Preparation of chromosomes; (4) Staining and banding; (5) Chromosomal analysis by light microscopy. The rest of the methodology was similar, as published in previous studies (Seabright, 1971; Waheed et al., 2018; Trejo et al., 2017). SPSS software (version 23) was used for all the statistical analyses, including frequencies and descriptive statistics.

\section{Results}

Among 202 patients (mean age of 21.5 years \pm 23.4 SD) with a known case of hematological malignancies were

Table 1. Demographic profile of hematological malignant patients.

\begin{tabular}{lcc}
\hline \multicolumn{1}{c}{ Variables } & $(\mathbf{n = 2 0 2})$ & (Percentage \%) \\
\hline Mean $\left( \pm \mathrm{SD}^{¥}\right)$ & 21.5 & $(23.4)$ \\
Gender wise distribution & & $(73)$ \\
$\quad$ Male & 147 & $(27)$ \\
$\quad$ Female & 55 & \\
Age Groups (years) & & $(2)$ \\
$\leq 01$ & 4 & $(24)$ \\
$2-10$ & 48 & $(20)$ \\
$11-20$ & 40 & $(17)$ \\
$21-30$ & 35 & $(8)$ \\
$31-40$ & 17 & $(3)$ \\
$41-50$ & 7 & $(6)$ \\
$51-60$ & 13 & $(13)$ \\
$61-69$ & 27 & $(5)$ \\
$\geq 70$ & 11 &
\end{tabular}

${ }^{{ }^{*} S D}$ : Standard Deviation; $\mathrm{n}=$ total number of patients. included in the current study. Gender-wise distribution revealed a pronounced predominance of the male population 147 (73\%), while the female population was 55 (27\%). The highest abnormalities, 48 (24\%), were reported in the age group of (2-10 years), whereas the minimum 04 (02\%) was reported in the age group ( $\leq 01$ years), as shown in Table 1 .

The maximum prevalence 66 (33\%) of these hematological disorders among the inclusive patients was Pre-B Acute Lymphoblastic Leukemia (Pre-B ALL), followed by 41 (20\%) Chronic Myelogenous Leukemia (CML), 29 (14\%) Acute Lymphoblastic Leukemia (ALL), 28 (14\%) Acute Myeloid Leukemia (AML), 15 (7\%) Chronic Lymphocytic Leukemia (CLL), 12 (6\%) MDS, 5 (2.4\%) Multiple Myeloma (MM) and other abnormalities 6 (3\%), respectively, as shown in Figure 2. Overall, 30 (15\%) of the prevalence of complex karyotypes was observed, as illustrated in Table 2. Among the stated hematological malignancies, the incidence of complex karyotypes was further studied. Surprisingly, the largest number of complex karyotypes was 17 (8\%) in pre-B-ALL, followed by ALL 10 (5\%). In these hematological malignancies, we have also examined chromosome aberrations. The most frequent chromosomal abnormality was the translocation seen in 50 (24.8\%) patients, followed by 10 (5\%) trisomy, 14 (6.9\%) hypotriploidy, 8 (4\%) monosomy, 7 (3.5\%) hyperdiploidy, and 5 (2.5\%) deletion. In contrast, a total of 103 (51\%) of patients were normal without any chromosomal aberration, as illustrated in Table 3.

These karyotypes have also been quantified by multiple hematological malignancies, as shown in Table 3. Deletion was overserved in ALL ( $n=3)$, MDS ( $n=1)$ and Pre-B ALL $(n=1)$. Similarly, other mutations were assessed which shows pattern as: Translocation in CML $(n=19)$, Pre-B ALL $(n=13), \operatorname{AML}(n=9), \operatorname{ALL}(n=4), \operatorname{MDS}(n=3)$ and $\operatorname{CLL}(n=1)$. The maximum number of a normal chromosome was found in Pre-B ALL $(n=32)$ and CML $(n=22)$. The combination of monosomy and hypodiploidy was only observed in patients with Burkitt and Jack 2 kinase positive disorders. Interestingly, the dicentric chromosome was only found in $\operatorname{ALL}(n=1)$, as shown in Table 3.

Inexplicably, identifying the high prevalence of Philadelphia chromosome with translocation $\mathrm{t}(9: 22)$ in 20 (10\%) patients was the most surprising finding in the current study. Gender-based studies found a higher prevalence in men $(n=16)$ and women $(n=4)$, as given in Figure 3.

Table 2. Distribution of different hematological disorders and hematological classifications.

\begin{tabular}{|c|c|c|c|c|c|c|c|}
\hline \multirow[t]{2}{*}{ Hematological Malignancies } & \multirow[t]{2}{*}{$(\mathbf{n}=202)$} & \multirow{2}{*}{$\begin{array}{c}\text { mean } \\
\pm S D\end{array}$} & \multirow{2}{*}{$\begin{array}{c}\text { Age } \\
\text { (Years) }\end{array}$} & \multicolumn{2}{|c|}{$\begin{array}{l}\text { Gender Wise } \\
\text { Distribution }\end{array}$} & \multicolumn{2}{|c|}{$\begin{array}{c}\text { Karyotype } \\
\text { Classification }\end{array}$} \\
\hline & & & & Male & Female & Normal & Complex \\
\hline Acute Lymphoblastic Leukemia & 29 & $10 \pm 16$ & $7-67$ & 17 & 12 & 19 & 10 \\
\hline Acute Myeloid Leukemia & 28 & $23 \pm 22$ & $3-87$ & 22 & 6 & 28 & 0 \\
\hline Pre-B Acute Lymphoblastic Leukemia & 66 & $11 \pm 10$ & $1-36$ & 49 & 17 & 49 & 17 \\
\hline Chronic Lymphocytic Leukemia & 15 & $57 \pm 12$ & $31-69$ & 10 & 5 & 15 & 0 \\
\hline Chronic Myelogenous leukemia & 41 & $39 \pm 21$ & $14-69$ & 23 & 18 & 41 & 0 \\
\hline Myelodysplastic Syndrome & 12 & $62 \pm 25$ & $15-83$ & 7 & 5 & 12 & 0 \\
\hline Multiple Myeloma & 5 & $68 \pm 2$ & $63-74$ & 4 & 1 & 5 & 0 \\
\hline $\begin{array}{l}\text { Other's (Burkit Lymphoma, Jack } 2 \\
\text { kinase mutation, Pancytopenia) }\end{array}$ & 6 & $43 \pm 20$ & $16-63$ & 6 & 0 & 3 & 3 \\
\hline
\end{tabular}


Table 3. Chromosomal aberrations in different hematological malignancies.

\begin{tabular}{|c|c|c|c|c|c|c|c|c|c|c|}
\hline \multirow{2}{*}{$\begin{array}{l}\text { Chromosomal } \\
\text { Abnormalities }\end{array}$} & \multirow{2}{*}{$\begin{array}{c}\text { Total } \\
(\mathbf{n}=202)\end{array}$} & \multirow{2}{*}{$(\%)$} & \multicolumn{8}{|c|}{ Hematological Malignancies } \\
\hline & & & ALL & AML & CLL & CML & MDS & MM & Pre-B-ALL & Others \\
\hline Deletion & 5 & 2.5 & 3 & & & & 1 & & 1 & \\
\hline Dicentric chromosomes & 1 & 0.5 & & & & & & & 1 & \\
\hline Hyperdiploidy & 7 & 3.5 & 3 & 1 & & & & & 3 & \\
\hline $\begin{array}{l}\text { Hypodiploidy and } \\
\text { monosomy }\end{array}$ & 2 & 1.0 & & & & & & & & 2 \\
\hline Heteroploidy & 1 & 0.5 & 1 & & & & & & & \\
\hline Hypotriploid & 14 & 6.9 & 8 & & & & & & 6 & \\
\hline Monosomy & 8 & 4.0 & & 3 & 1 & & & & 3 & 1 \\
\hline Normal & 103 & 51.0 & 7 & 14 & 13 & 22 & 8 & 5 & 32 & 3 \\
\hline Tetrasomy & 1 & 0.5 & & & & & & & & 1 \\
\hline Translocation & 50 & 24.8 & 4 & 9 & & 1 & 19 & 3 & & 13 \\
\hline Trisomy & 10 & 5.0 & 3 & 1 & & & & & & 6 \\
\hline
\end{tabular}

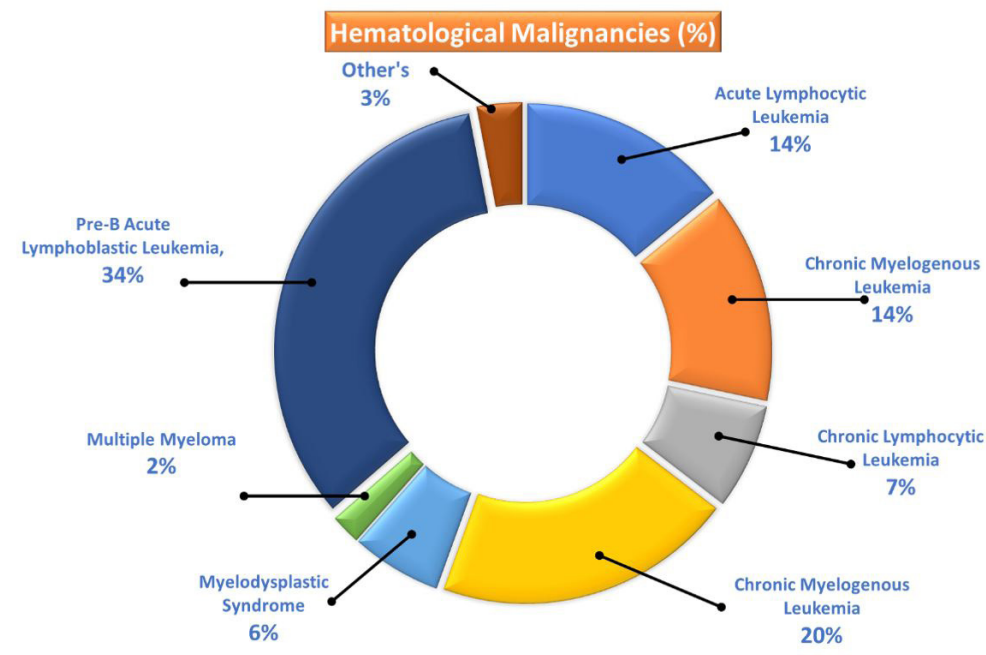

Figure 2. Prevalence of hematological malignancies in patients.

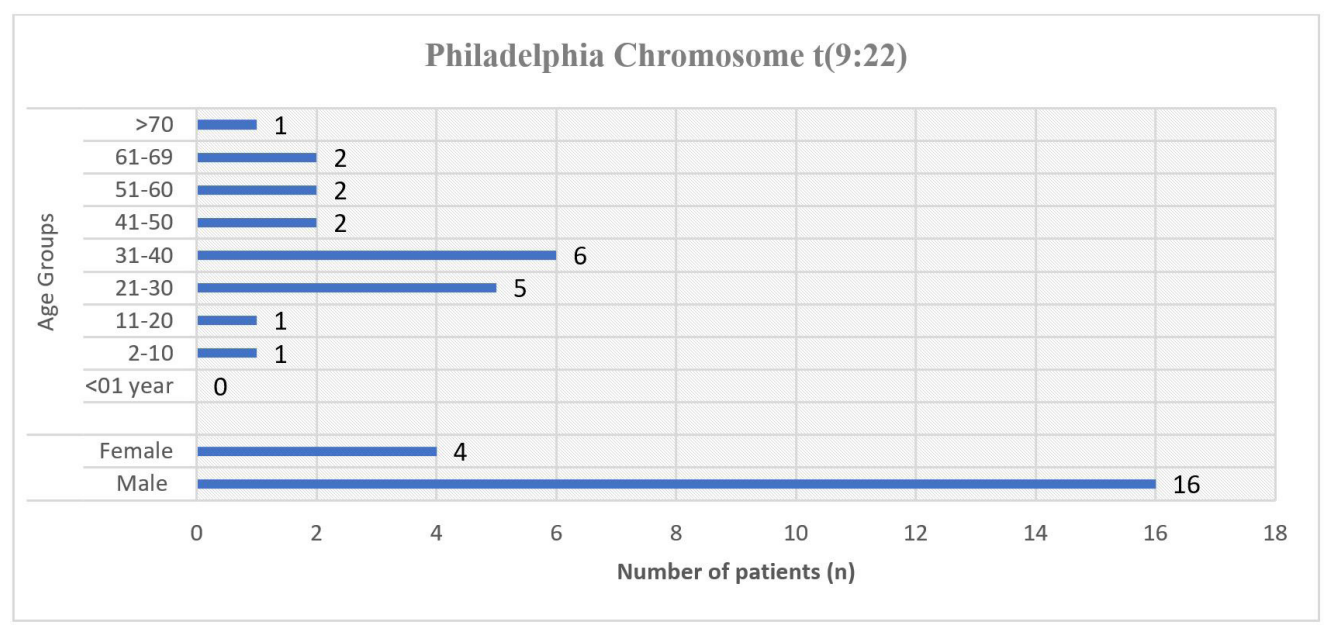

Figure 3. Prevalence of Philadelphia chromosome with $\mathrm{t}(9: 22)$ among different age groups and genders. 


\section{Discussion}

Karyotyping and cytogenetic studies of hematological diseases have shown the prognostic impact of chromosomal abnormalities on the diagnosis and treatment of patients over the last three decades. (Malakzai et al., 2020; Grimwade et al., 2001). WHO categorized the hematological neoplasms, but clonal abnormality detection provides the detail insights of prognostic and therapeutics in malignant or premalignant disorders (Mitelman et al., 2018). The prevalence of hematological neoplasms identified by genetic anomalies is proliferating as is the number of specific therapeutic methods directly or indirectly addressing congenital abnormalities. Genetic profiling is also an essential factor of treatment response, diagnosis, prognosis and surveillance (Rack et al., 2019). In developing countries, the incidence of cancer is rising rapidly. Therefore, the current research is intended to address the gap in the literature on cytogenetic disorders in hematological patients in Pakistan with 3\% leukemia in the city of Lahore city, having second highest population in Pakistan (Badar et al., 2016).

In the current study, a total of 202 patients was enrolled with a mean age of 21.5 years, contrary to the different studies conducted in other regions of Asia (Yaghmaei et al., 2009). The average age of 37 years was recorded in another study in Pakistan (Waheed et al., 2018). Besides, the mean age of around 50 years was reported in European countries (Stölzel et al., 2016). This might be due to the difference in geographical areas. The existence of complex karyotypes is defined as bearing more than three unrelated chromosomal aberrations, and the prognostic factor of AML cases has been the most frequently used (Motlló et al., 2014). Nevertheless, in the present research, most complex karyotype 17 (56.6\%) were observed in patients with pre-B ALL diagnoses.

According to our study's gender distribution, males had the highest prevalence of hematological disorders, at 147 (73\%), compared to females, who had a prevalence of 55 (27\%). The current study's findings are consistent with previous studies conducted in Pakistan, which recorded a higher incidence of hematological malignancies in males than in females (Harani et al., 2006; Zehra et al., 2016). In addition, Waheed et al., reported an $80 \%$ prevalence of leukemia in males and relative to the female population in Pakistan (Waheed et al., 2018).

The incidence of chromosome aberrations in the current study was 99 (49\%), higher than that recorded in Mexico, $33 \%$ (Trejo et al., 2017) as compared to other studies (Mrózek et al., 2012; Zhou et al., 2016). The maximum prevalence of these hematological disorders for inclusive patients was 66 (33\%) pre-B ALL. Few previous studies have identified a similar prevalence of hematological disorders (Luquet et al., 2008). In contrast, in the current report, the prevalence of MSD was 12 (6\%) than the previous report conducted in Pakistan (Waheed et al., 2018). According to the WHO classification, new prognostic variables, such as molecular markers and chromosome translocations, lowered the minimum blast cells threshold to $20 \%$, including the high-grade MDS in the FAB framework (Kumar, 2011). This authenticates the previous findings of a study that recorded the highest translocations in hematological malignancies (Brunstein et al., 2002). In addition, the incidence of trisomy in malignancies was in accordance with the previous studies from Pakistan (Waheed et al., 2018) and with international data (Yang et al., 2012; Cortes et al., 1995).

The most important approach for the diagnosis of AML is cytogenetic analysis, and the WHO classification is based on molecular genetics and karyotyping (Shaikh et al., 2018). The majority of AML cases are caused by non-random chromosomal translocations that frequently lead to altered gene expression. The most significant prognostic factor for determining remission rate, relapse rate, and overall survival is cytogenetics (Dhall et al., 2019). However, in the current study, chromosomal translocation was predominantly seen in AML patients. Kumar (2011), also reported the occurrence of translocation in AML patients (Kumar, 2011). On the other hand, CML is characterized as the translocation of $\mathrm{t}(9 ; 22)$ ( $\mathrm{q} 34 ; \mathrm{q} 11.2)$, also known as the Philadelphia Chromosome. This form of chromosome anomaly moves the Abelson murine leukemia (ABL1) oncogene to chromosome 9q34 to breakpoint cluster area (BCR) on chromosome 22q11, resulting in BCR / ABL1 gene fusion (Johansson et al., 2002). Therefore, BCR-ABL mutation characterized as breaking and switching the position of BCR and ABL genes (Acar and Uz, 2018). In the present study, translocation $t(9: 22)$ was a significant anomaly in CML situations, consistent with the findings recorded by Waheed et al. (2018).

The karyotype remains the "gold standard" in our institutions to validate diagnosis, forecast and classify multiple hematological disorders. Although cytogenetic diagnosis is low sensitivity, it is still commonly used in the evaluation of patients with clinical remission or after hematopoietic stem cell transplantation. To conclude, the current study presents the importance of cytogenetic analysis and chromosomal defects in Pakistan's most prevalent hematological malignancies. Translocation was considered the most common aberration; we analyzed the diverse karyotypes of various leukemias for structural and numerical chromosomal changes. As a result, this study suggests determining the chromosomal structure of each hematological malignancy for the purposes of good prognosis and disease control.

\section{References}

ACAR, K. and UZ, B., 2018. A chronic myeloid leukemia case with a variant translocation $\mathrm{t}(11 ; 22)(\mathrm{q} 23 ; \mathrm{q} 11.2)$ : masked Philadelphia or simple variant translocation? The Pan African Medical Journal, vol. 30, pp. 161. PMid:30455790.

BADAR, F., MAHMOOD, S., YUSUF, M.A. and SULTAN, F., 2016. Epidemiology of cancers in Lahore, Pakistan, 2010-2012: a crosssectional study. BMJ Open, vol. 6, no. 6, e011828. PMid:27354082.

BRUNSTEIN, C.G., DYLLA, S.J. and VERFAILLIE, C.M., 2002. Chromosomal translocations in hematologic malignancies. Current Genomics, vol. 3, no. 4, pp. 313-334.

CORTES, J.E., KANTARJIAN, H., O'BRIEN, S., KEATING, M., PIERCE, S., FREIREICH, E.J. and ESTEY, E., 1995. Clinical and prognostic significance of trisomy 21 in adult patients with acute 
myelogenous leukemia and myelodysplastic syndromes. Leukemia, vol. 9, no. 1, pp. 115-117. PMid:7845005.

DHALL, A., ZEE, B.M., YAN, F. and BLANCO, M.A., 2019. Intersection of epigenetic and metabolic regulation of histone modifications in acute myeloid leukemia. Frontiers in Oncology, vol. 9, pp. 432. PMid:31192132.

DÖHNER, H., ESTEY, E.H., AMADORI, S., APPELBAUM, F.R., BÜCHNER, T., BURNETT, A.K., DOMBRET, H., FENAUX, P., GRIMWADE, D., LARSON, R.A., LO-COCO, F., NAOE, T., NIEDERWIESER, D., OSSENKOPPELE, G.J., SANZ, M.A., SIERRA, J., TALLMAN, M.S., LÖWENBERG, B. and BLOOMFIELD, C.D., 2010. Diagnosis and management of acute myeloid leukemia in adults: recommendations from an international expert panel, on behalf of the European LeukemiaNet. Blood, vol. 115, no. 3, pp. 453-474. PMid:19880497.

GRIMWADE, D., WALKER, H., HARRISON, G., OLIVER, F., CHATTERS, S., HARRISON, C.J., WHEATLEY, K., BURNETT, A.K. and GOLDSTONE, A.H., 2001. The predictive value of hierarchical cytogenetic classification in older adults with acute myeloid leukemia (AML): analysis of 1065 patients entered into the United Kingdom Medical Research Council AML11 trial. Blood, vol. 98, no. 5, pp. 1312-1320. PMid:11520776.

HARANI, M.S., ADIL, S., KAKEPOTO, G.N., KHILJI, Z., SHAIKH, U. and KHURSHID, M., 2006. Significance of cytogenetic abnormalities in acute myeloid leukaemia. The Journal of the Pakistan Medical Association, vol. 56, no. 1, pp. 9-13. PMid:16454127.

HAUS, O., POLUHA, A. and SKONIECZKA, K., 2012. Cytogenetics in hematology. Molecular Aspects of Hematologic Malignancies. Springer.

JOHANSSON, B., FIORETOS, T. and MITELMAN, F., 2002. Cytogenetic and molecular genetic evolution of chronic myeloid leukemia. Acta Haematologica, vol. 107, no. 2, pp. 76-94. PMid:11919388.

KUMAR, C.C., 2011. Genetic abnormalities and challenges in the treatment of acute myeloid leukemia. Genes \& Cancer, vol. 2, no. 2, pp. 95-107. PMid:21779483.

LUQUET, I., LAI, J., BARIN, C., BARANGER, L., BILHOU-NABERA, C., LIPPERT, E., GERVAIS, C., TALMANT, P., CORNILLET-LEFEBVRE, P., PEROT, C., NADAL, N., MOZZICONACCI, M.J., LAFAGEPOCHITALOFF, M., ECLACHE, V., MUGNERET, F., LEFEBVRE, C., HERENS, C., SPELEMAN, F., POIREL, H., TIGAUD, I., CABROL, C., ROUSSELOT, P., DALIPHARD, S., IMBERT, M., GARAND, R., GENEVIÈVE, F., BERGER, R. and TERRE, C., 2008. Hyperdiploid karyotypes in acute myeloid leukemia define a novel entity: a study of 38 patients from the Groupe Francophone de Cytogenetique Hematologique (GFCH). Leukemia, vol. 22, no. 1, pp. 132-137. PMid:17928884.

MALAKZAI, H.A., RAHMANI, S., HAIDARY, A.M., NOOR, S., AHMAD, M., IBRAHIMKHIL, A.S. and SHARIF, S., 2020. Complex cytogenetic abnormalities in chronic myeloid leukemia resulting in early progression to blast crisis: a case report. Journal of Medical Case Reports, vol. 14, no. 1, pp. 231. PMid:33243265.

MITELMAN, F., JOHANSSON, B. and MERTENS, F., 2018 [viewed 16 March 2021]. Mitelman database of chromosome aberrations and gene fusions in cancer [online]. Bethesda: National Institutes of Health. Available from: cgap.nci.nih.gov/Chromosomes/ Mitelman

MOTLLÓ, C., RIBERA, J.M., MORGADES, M., GRANADA, I., MONTESINOS, P., GONZÁLEZ-CAMPOS, J., FERNÁNDEZ-ABELLÁN, P., TORMO, M., BETHENCOURT, C., BRUNET, S., HERNÁNDEZRIVAS, J.M., MORENO, M.J., SARRÀ, J., DEL POTRO, E., BARBA, P., BERNAL, T., GRANDE, C., GRAU, J., CERVERA, J. and FELIU, E., 2014. Prognostic significance of complex karyotype and monosomal karyotype in adult patients with acute lymphoblastic leukemia treated with risk-adapted protocols. Cancer, vol. 120, no. 24, pp. 3958-3964. PMid:25116331.

MRÓZEK, K., 2008. Cytogenetic, molecular genetic, and clinical characteristics of acute myeloid leukemia with a complex karyotype. Seminars in Oncology, vol. 35, no. 4, pp. 365377. http://dx.doi.org/10.1053/j.seminoncol.2008.04.007. PMid: 18692687.

MRÓZEK, K., MARCUCCI, G., NICOLET, D., MAHARRY, K.S., BECKER, H., WHITMAN, S.P., METZELER, K.H., SCHWIND, S., WU, Y.-Z., KOHLSCHMIDT, J., PETTENATI, M.J., HEEREMA, N.A., BLOCK, A.W., PATIL, S.R., BAER, M.R., KOLITZ, J.E., MOORE, J.O., CARROLL, A.J., STONE, R.M., LARSON, R.A. and BLOOMFIELD, C.D., 2012. Prognostic significance of the European LeukemiaNet standardized system for reporting cytogenetic and molecular alterations in adults with acute myeloid leukemia. Journal of Clinical Oncology, vol. 30, no. 36, pp. 4515-4523. PMid:22987078.

PRAKASH, G., KAUR, A., MALHOTRA, P., KHADWAL, A., SHARMA, P., SURI, V., VARMA, N. and VARMA, S., 2016. Current role of genetics in hematologic malignancies. Indian Journal of Hematology \& Blood Transfusion: an Official Journal of Indian Society of Hematology and Blood Transfusion, vol. 32, no. 1, pp. 18-31. PMid:26855503.

RACK, K., VAN DEN BERG, E., HAFERLACH, C., BEVERLOO, H.B., COSTA, D., ESPINET, B., FOOT, N., JEFFRIES, S., MARTIN, K., O'CONNOR, S., SCHOUMANS, J., TALLEY, P., TELFORD, N., STIOUI, S., ZEMANOVA, Z. and HASTINGS, R.J., 2019. European recommendations and quality assurance for cytogenomic analysis of haematological neoplasms. Leukemia, vol. 33, no. 8, pp. 1851-1867. PMid:30696948.

RICHKIND, K., 2012. The role of classical cytogenetics in hematologic diagnosis. In: B.H. DAVIS and K. KOTTKE-MARCHANT, eds. Laboratory hematology practice. Chichester: Blackwell Pub.

RÖLLIG, C., BORNHÄUSER, M., THIEDE, C., TAUBE, F., KRAMER, M., MOHR, B., AULITZKY, W., BODENSTEIN, H., TISCHLER, H.-J., STUHLMANN, R., SCHULER, U., STÖLZEL, F., VON BONIN, M., WANDT, H., SCHÄFER-ECKART, K., SCHAICH, M. and EHNINGER, G., 2011. Long-term prognosis of acute myeloid leukemia according to the new genetic risk classification of the European LeukemiaNet recommendations: evaluation of the proposed reporting system. Journal of clinical oncology, vol. 29, no. 20, pp. 2758-2765. PMid:21632498.

SÁNCHEZ, S., SWARÇA, A.C. and FENOCCHIO, A.S., 2014. Cytogenetics analyses among populations of the fish Iheringichtys labrosus (Kröyer, 1874. (Siluriformes, Pimelodidae). Karyotype analysis, C-banding and AgRONs distribution. Brazilian Journal of Biology = Revista Brasileira de Biologia, vol. 74, no. 1, pp. 212-216. http:// dx.doi.org/10.1590/1519-6984.13212. PMid:25055104.

SEABRIGHT, M., 1971. A rapid banding technique for human chromosomes. Lancet, vol. 298, no. 7731, pp. 971-972. http:// dx.doi.org/10.1016/S0140-6736(71)90287-X. PMid:4107917.

SHAFFER, L.G., MCGOWAN-JORDAN, J. and SCHMID, M., 2013. ISCN 2013: an international system for human cytogenetic nomenclature. Farmington: Karger Medical and Scientific Publishers.

SHAIKH, M.S., AHMED, Z.A., SHAIKH, M.U., ADIL, S.N., KHURSHID, M., MOATTER, T., RASHID, A., KARIM, F., RAHEEM, A. and ALI, N., 2018. Distribution of chromosomal abnormalities commonly observed in adult acute myeloid leukemia in Pakistan as predictors of prognosis. Asian Pacific Journal of Cancer Prevention, vol. 19, no. 7, pp. 1903-1906. PMid:30049204.

SIEGEL, R., WARD, E., BRAWLEY, O. and JEMAL, A., 2011. Cancer statistics, 2011: the impact of eliminating socioeconomic and racial disparities on premature cancer deaths. CA: a cancer journal for clinicians, vol. 61, no. 4, pp. 212-236. PMid:21685461. 
STÖLZEL, F., MOHR, B., KRAMER, M., OELSCHLÄGEL, U., BOCHTLER, T., BERDEL, W.E., KAUFMANN, M., BALDUS, C.D., SCHÄFERECKART, K., STUHLMANN, R., EINSELE, H., KRAUSE, S.W., SERVE, H., HÄNEL, M., HERBST, R., NEUBAUER, A., SOHLBACH, K., MAYER, J., MIDDEKE, J.M., PLATZBECKER, U., SCHAICH, M., KRÄMER, A., RÖLLIG, C., SCHETELIG, J., BORNHÄUSER, M. and EHNINGER, G., 2016. Karyotype complexity and prognosis in acute myeloid leukemia. Blood Cancer Journal, vol. 6, no. 1, pp. e386-e386. PMid:26771812.

TREJO, R.A., DEL CASTILLO MORENO, A., CARMONA, L.A., CEDILLO, V.M., IPIÑA, J.K., ROMERO, M.G., PEREDO, A.C., FULLER, E.R., MARTÍNEZ, E.A. and CABRERA, A.P., 2017. Chromosomal abnormalities in patients with haematologic malignancies in the General Hospital of Mexico. Revista Medica del Hospital General, vol. 80, no. 2, pp. 87-91.

WAHEED, S., HASSAN, J., NAZ, M., MAQSOOD, S., ABID, M., SHAN, S., NADEEM, M. and SHAMSI, T.S., 2018. Complex karyotype in hematological diseases: a 6-year single centre study from Pakistan. Journal of Oncology, vol. 2018, pp. 2019239. http:// dx.doi.org/10.1155/2018/2019239. PMid:29971104.

YAGHMAEI, M., GERAYELI, N., GHAFARI, S., GHAVAMZADEH, A. and TOUTIAN, S., 2009. Some specific chromosomal aberrations of hematologic malignancies in 80 iranian population. International
Journal of Hematology-Oncology and Stem Cell Research, vol. 3, no. 3, pp. 28-33.

YANG, X.-F., SUN, A.-N., YIN, J., CAI, C.-S., TIAN, X.-P., QIAN, J., CHEN, S.-N. and WU, D.-P., 2012. Monosomal karyotypes among 1147 Chinese patients with acute myeloid leukemia: prevalence, features and prognostic impact. Asian Pacific Journal of Cancer Prevention, vol. 13, no. 11, pp. 5421-5426. PMid:23317194.

ZAGOZDZON, R. and GOLAB, J., 2015. Cancer stem cells in haematological malignancies. Contemporary Oncology, vol. 19, no. 1A, pp. A1-A6. PMid:25691816.

ZAPPES, I.A., PORTELLA, A.D.S. and LESSA, G.M., 2014. Description of karyotype of Kerodon acrobata, an endemic rodent in Brazilian Cerrado. Brazilian Journal of Biology = Revista Brasileira de Biologia, vol. 74, no. 1, pp. 251-256. PMid:25055111.

ZEHRA, S., NAJAM, R., FARZANA, T. and SHAMSI, T.S., 2016. Outcomes of 1 st remission induction chemotherapy in acute myeloid leukemia cytogenetic risk groups. Asian Pacific Journal of Cancer Prevention, vol. 17, no. 12, pp. 5251-5256. PMid:28125870.

ZHOU, Y., KANAGAL-SHAMANNA, R., ZUO, Z., TANG, G., MEDEIROS, L.J. and BUESO-RAMOS, C.E., 2016. Advances in B-lymphoblastic leukemia: cytogenetic and genomic lesions. Annals of Diagnostic Pathology, vol. 23, pp. 43-50. http://dx.doi.org/10.1016/j. anndiagpath.2016.02.002. PMid:27130145. 